\title{
There is no "point" in decision-making: a model of transactive rationality for public policy and administration
}

\author{
Shyama Kuruvilla $\cdot$ Philipp Dorstewitz
}

Published online: 7 July 2009

(C) The Author(s) 2009. This article is published with open access at Springerlink.com

\begin{abstract}
The hope that policy-making is a rational process lies at the heart of policy science and democratic practice. However, what constitutes rationality is not clear. In policy deliberations, scientific, democratic, moral, and ecological concerns are often at odds. Harold Lasswell, in instituting the contemporary policy sciences, found that John Dewey's pragmatist philosophy provided an integrative foundation that took into account all these considerations. As the policy sciences developed with a predominantly empirical focus on discrete aspects of policy-making, this holistic perspective was lost for a while. Contemporary theorists are reclaiming pragmatist philosophy as a framework for public policy and administration. In this article, key postulates of pragmatist philosophy are transposed to policy science by developing a new theoretical model of transactive rationality. This model is developed in light of current policy analyses, and against the backdrop of three classical policy science theories of rationality: linear and bounded rationalism; incrementalism; and mixed-scanning. Transactive rationality is a "fourth approach" that, by integrating scientific, democratic, moral, and ecological considerations, serves as a more holistic, explanatory, and normative guide for public policy and democratic practice.
\end{abstract}

Keywords Public policy · Public administration - Rationality · Transactive rationality · Pragmatist philosophy $\cdot$ Science $\cdot$ Democracy $\cdot$ Morality $\cdot$ Ecological $\cdot$ John Dewey

\footnotetext{
S. Kuruvilla (ه)

Department of International Health, School of Public Health, Boston University, 801 Massachusetts Avenue, 3rd Floor, Boston, MA 02118, USA

e-mail: shyamask@bu.edu; shyama@me.com

P. Dorstewitz

Department of Philosophy, Maastricht University, Grote Gracht 80-82, PO Box 616, Maastricht, The Netherlands

e-mail: p.dorstewitz@maastrichtuniversity.nl
} 


\section{Introduction}

People across society would prefer that public policy-making is "rational". Sound reasoning should make for well-informed decisions and successful strategies. However, different perspectives proffer conflicting opinions on what constitutes rationality. A traditional view in public administration is that rationality is a scientific, or technical, mode of reasoning that is employed to achieve political ends or goals-without questioning the morality, or worth, of these ends (Meyerson and Banfield 1955; Simon 1983). Increasingly, policy analysts view this separation of political ends from technical means as a "moral disaster" in the theory and practice of modern public administration (DeLeon and Longobardi 2002; Garrison 2000; Richardson 2002). Later theories of public policy and deliberation explicitly include democratic, moral, and ecological considerations (Alexander 1993; Habermas 1987). There are further divergent challenges to rationality in policymaking. As Nelkin (1975) indicates: "The complexity of public decisions seems to require highly specialized and esoteric knowledge, and those who control this knowledge have considerable power." Yet, by democratic standards, people have the right to participate in decisions that affect their lives (Nelkin 1975; Steiner and Alston 2000). Different frames of reference that are used to evaluate public policy, further exacerbate the tension between demands for expert knowledge and public participation. Scientific, ideological, economic, political, procedural, cultural, or ecological frames often produce incompatible recommendations (Durie 2004; Roth et al. 2003). For example, Roth et al. (2003) analyzed public commentary on proposed Food and Drug Administration regulations in the U.S. and concluded:

Though scientists and regulatory experts may identify and present scientific evidence to indicate proposed regulations' technical rationality, the social problems that these regulations address may always be reframed in moral terms that undermine the regulation's legitimacy. (Roth et al. 2003, p. 36)

In policy science, public administration, and planning, the classic models of rationality are: linear rationalism (Meyerson and Banfield 1955); bounded rationality (Simon 1957); incrementalism (Lindblom 1959); and mixed scanning (Etzioni 1967). These models describe policy processes and offer alternative perspectives on how these processes may be rationally organized. Other policy theories describe diverse aspects of policy-making based on empirical analyses, for example, of: agenda setting; policy networks and advocacy coalitions; policy formulation; and implementation (John 1998; Kingdon 1995; Parsons 1995; Sabatier 1999). This plethora of theoretical and empirical perspectives is not sufficiently integrated to provide an explanatory overview of policy-making, or to serve as a normative guide for rational public policy. Policy theorists recognize the need for more holistic, explanatory, and normative policy theory (deHaven-Smith 1988; DeLeon and Longobardi 2002; John 1998; Parsons 1995; Sabatier 1999). One of the main challenges to achieving this goal, as deHaven-Smith (1988) asserts in Philosophical Critiques of Policy Analysis, is that:

The facts confront us like pebbles in a kaleidoscope, capable of being rearranged and reinterpreted with a twist of the theoretical lens. It is time to discard this fruitless approach to policy analysis and to explore alternatives grounded in comprehensive social and political theory. (deHaven-Smith 1988, p. 126) 
This article posits that classical pragmatist philosophy provides a comprehensive epistemology for the policy sciences. This idea is not new and is, in fact, the foundation on which the contemporary policy sciences were built. As Harold Lasswell acknowledged:

The policy sciences are a contemporary policy adaptation of the general approach to public policy that was recommended by John Dewey and his colleagues in the development of American pragmatism. (Lasswell 1971, p. xiv)

Dewey developed a holistic philosophy that sought to improve rationality in human agency by integrating the scientific, democratic, moral, and ecological dimensions of reasoning. This holistic perspective was lost as policy science developed with a more narrow technical and empirical focus. There is now growing interest in reclaiming Deweyan pragmatist philosophy as a comprehensive blueprint for public policy and democratic practice (Bernstein 1998; Dorstewitz and Kuruvilla 2007; Evans 2000; Joas 1996; Mousavi and Garrison 2003; Ryan 2000; Shields 2003; Shook 2003; Snider 2000; Westbrook 1991). The objective of this article is to transpose rationality as envisioned in pragmatist philosophy to policy science. In order to do this, a new model of rational public policy is developed.

The task of applying classical Deweyan pragmatism to contemporary policy science is not without its challenges. Consider Dewey's definition of rationality:

Rationality is not a force to evoke against impulse and habit. It is the attainment of a working harmony among diverse desires. "Reason" as a noun signifies the happy cooperation of a multitude of dispositions, such as sympathy, curiosity, exploration, experimentation, frankness, pursuit-to follow things through-circumspection, to look about at the context, and so on. The elaborate systems of science are born not of reason but of impulses at first slight and flickering; impulses to handle, move about, to hunt, to uncover, to mix things separated and divide things combined, to talk, and to listen. Method is their effectual organization into continuous dispositions of inquiry, development, and testing. It occurs after these acts and because of their consequences. Reason, the rational attitude, is the resulting disposition, not a ready-made antecedent which can be invoked at will and set into movement. (Dewey 1922/2002, p. 196)

Not only is this a complex, possibly abstruse, explanation, but it also draws on the depth and breadth of Dewey's comprehensive and integrative study. ${ }^{1}$ Pragmatist scholars caution against a piecemeal reading of pragmatist philosophy and recommend that Dewey's study be synthesized and systematized, before application (Caspary 2000; Garrison 2000; Hickman 2004; Ryan 1995; Schilpp and Hahn 1939/1989; Snider 2000). Four foundational constructs in pragmatist philosophy are used to build the new model of rationality in this article. These constructs are presented here as "postulates"

I. the starting point of rationality is not a predefined problem or goal, but an indeterminate situation;

\footnotetext{
${ }^{1}$ Dewey wrote over 400 journal articles and 40 books. He also gave a series of public speeches and lectures, and wrote essays, policy briefs, letters, and articles in popular magazines and newspapers, including in the New Republic and New York Times. Dewey's work is now made increasingly accessible through recent reprints, analyses, anthologies, biographies, and online resources. Notably, the Center for Dewey Studies has compiled a thirty-seven-volume edition of Dewey's collected works (1882-1953) that is also available as a searchable electronic database http://www.siuc.edu/ deweyctr/resources.htm\#collection.

2 The term postulate is used here to reflect the fact that much of Dewey's philosophy is constructed as inference or argument that he fully intended should be tested and further developed through inquiry and application. For example, in his theory of ethics, Dewey explicitly refers to "The Ethical Postulate".
} 
II. rationality is a product of inquiry in democratic communities;

III. rationality integrates scientific, moral, and ecological reasoning; and

IV. rationality is only successful if it serves as a guide towards satisfactory consequences in both theory and practice.

These postulates are transposed to a new model of rational public policy, the transactive rationality model, which is presented as a "fourth approach" to linear rationalism, incrementalism, and mixed-scanning. By integrating scientific, democratic, moral, and ecological considerations, pragmatist rationality serves as a more holistic, explanatory, and normative guide for public policy and democratic practice.

\section{Postulate I. The starting point of rationality is not a predefined problem or goal, but an indeterminate situation}

Linear rationality is a primary reference for most other models of rationality, which are either modifications of this model or explicit rejections of it (Dorstewitz and Kuruvilla 2007; Schoenwandt 2008). The starting point for agency in linear rational models (Fig. 1), based on Humean psychology, is a pre-defined, given set of "ends" (e.g., "passions," p, problems, or goals). These ends are matched with available "means" (e.g., beliefs, resources, and guides—-such as practice standards), which are then implemented to address or achieve the ends.

In policy theory, linear rationality is reflected in the seemingly ubiquitous "stages" model (Parsons 1995; Sabatier 1999). The stages model depicts policy-making as moving through distinct steps of policy agenda setting, formulation, decision-making, implementation, and evaluation. In policy practice, linear rational thinking is evident when public preferences and political positions are invoked as inviolate guides for future policy projects. The classic rationality models also explicitly, or implicitly, assume that policy problems and purposes "exist" outside inquiry and deliberation processes. Bounded rationality recognizes that there are contextual constraints to coordinating knowledge and action to maximize given ends. Rationality is then not the development of ultimate or optimal strategies, but a "satisficing" or "bounded" search for solutions given these constraints (Simon 1957). Incrementalism rejects the idea of centrally conceived planning, and instead, describes a continuum of decentralized, incremental changes that demand frequent review, but that are oriented to some overarching goal (Lindblom 1959). Etzioni (1967) proposed "mixed scanning" as a "third approach" to Simon's bounded rationality and Lindblom's incrementalism. Mixed scanning is a search process that combines a wide perspective on potential policy solutions, with an in-depth analysis of the most compelling options, but what constitutes a policy problem seems unproblematic.

The linear rational model is untenable on empirical, theoretical, and moral grounds. In practice, public policy problems and goals are rarely well defined at the outset. Analysts describe insufficiently understood, indeterminate, and "messy" problematic situations as the starting point of most public planning and policy projects (Checkland 1999; Rosenhead and Mingers 2001; Shields 2003). In order to counteract the linear stages theory of policy-

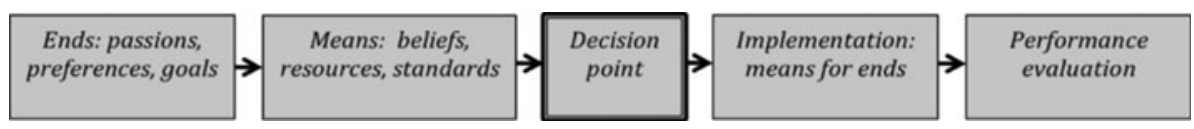

Fig. 1 The linear rational model 
making, contemporary theorists provide a vivid assortment of alternative images. These include: "the layered formation of a pearl" (Weiss 1980); "cubist paintings" and "mosaics" (Shields 1996); "garbage cans" (Cohen et al. 1972); "concurrent streams of policy, politics and problems," and "windows of opportunity" (Kingdon 1995).

From a moral perspective, ends and desires that are not subject to inquiry and deliberation can be perverse. In order to illustrate this point, Elster (1991) recounts the fable of Aesop's fox who, on unsuccessfully trying to reach a desired bunch of grapes, mitigated his disappointment by deciding that the "grapes were sour". Conversely, the "grass is greener on the other side of the fence" syndrome is associated with desires that are permanently beyond reach (Elster 1991). Ends that remain unexamined, because they are considered as "given," can lead to illogical conclusions and undesirable consequences. If "given" or unexamined ends can be perverse, then finding ways to gratify them, may neither be in anyone's interest, nor a moral exercise according to a wider view of rationality (Richardson 2002).

\section{Indeterminate situations as "practical starting points" in pragmatist philosophy}

A century earlier, John Dewey reflected on the indeterminate nature of problematic situations (Dewey 1910/1997, 1994). He concluded that it was untenable to separate reflection on strategies and constraints from reflection on related ends and preferences. In pragmatist philosophy, an indeterminate situation is the "practical starting point" for rational agency (cf. Hildebrand 1999). In order to establish this alternative starting point for rational agency (i.e., as opposed to a pre-defined end or passion), Dewey began by explaining how transactions constitute situations, and how situations turn indeterminate. "Transaction" is an important, and complex, concept in Dewey's philosophy, and is foundational to the new transactive rationality model in this article. This model integrates transactions and relationships that are formative of rational policy inquiry, deliberation, and change.

All living beings are continually engaged in transactions to maintain, or regain, an organic equilibrium. Transactions, as active life processes, involve both organism and environment acting together in a composite unity. Dewey termed this composite transactive unity as a "situation". In any specific functional context, a situation comprises the diversity and multiple dimensions of related transactions (including biological activity, social habits, individual thoughts, cultural values, and natural environments) (Dewey 1910/ 1997, 1994). In the context of policy-making, Hall (1977) describes policy environments as comprising institutional, technological, legal, political, economic, demographic, ethical, ideological, ecological, and cultural dimensions.

Dewey and Bentley (1946) differentiated transaction from self-action (subjects acting under their own power and volition, as rational choice theories imply) and inter-action (subjects and objects relating as separate entities, as the behaviorist stimulus-response, or cause-effect, model suggests). In transaction, there is no "final attribution to 'elements' or other presumptively detachable or independent "entities'" (Dewey and Bentley 1946, p. 509). Classical pragmatist philosophy defines transaction in this specific technical way. However, the quotidian use of the word conveys a sense that is more like interaction (i.e., buying and selling, cause and effect). In order to avoid misinterpretation, in this article the word "transactive" is also used in place of "transaction," drawing on contemporary pragmatist scholars' use of this term. For example, Seigfried (1996, pp. 145-146) emphasizes that the "transactive character of experience is its most salient characteristic for pragmatists. Self and world, thought and action, are reciprocally related." 
Transactions and situations in pragmatist philosophy are congruent with "systems" thinking in policy-making and public administration (Ackoff and Emory 2005; Checkland 1999; Vickers 1965). Though parts and actions in a system can be considered independently, only together do they constitute a coherent whole. In a systems view, entities are not defined as static objects, but in terms of their dynamic, functional relations. As Sir Geoffery Vickers (1978), a progenitor of systems thinking in public administration, explained in an interview:

Having been a lawyer and an administrator, I am interested in Systems from the personal up to the very large, human, social systems, I am also interested in systems of concepts and values through which we see all the others which I call appreciative systems.

When situations, or systems, comprise regular, functionally coordinated transactions, a habitual equilibrium is achieved. When habitual equilibrium is interrupted, an indeterminate situation results. Intentional transactions, or agency, are then originated and oriented to define the problematic situation, respond, and achieve a new equilibrium (Dewey 1910/1997, 1994). In policy-making, Kingdon (1995) describes an ongoing flow of activities in politics, problem, and policy streams. At certain points, these streams converge, changing the situation, and creating conditions or opportunities, for policy change.

Agency (or intentional, creative action as opposed to habitual action) forms and evolves in the attempt to clarify and settle indeterminate situations (Dewey 1939/1989b; Joas 1996; Mousavi and Garrison 2003). Though human agency develops in response to indeterminate situations, not all forms of agency are rational. By Dewey's (1922/2002, p. 192) definition of rationality, agency requires "method" to evaluate diverse desires, habits, plans of action, and consequences. The method that Dewey recommends for rational agency is the Logic of Inquiry presented in a following section. In general, Dewey saw human agency as a quest to attain new dynamic forms of equilibrium within ever-changing situational contexts. He viewed human experience as progressing through a continual "rhythm of situations": from habitual to indeterminate, problematic, and then to new equilibrium (as depicted in Fig. 2).

In policy theory, Baumgartner and Jones (1991) describe a similar transition between stability and instability in their punctuated equilibrium model of policy-making. Their model is critiqued because it does not satisfactorily explain the transition between stability and change (John 1998). Similarly, incrementalism recognizes that policy change occurs in

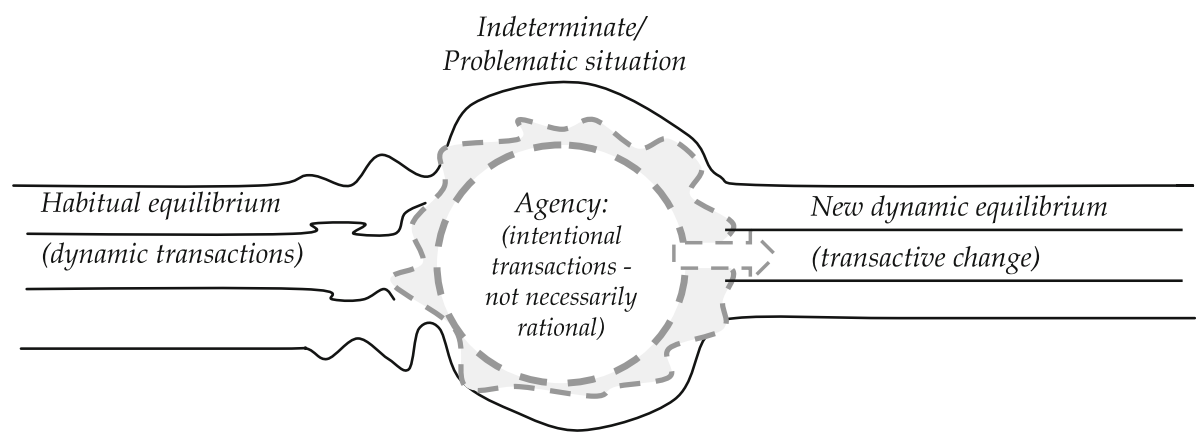

Fig. 2 The rhythm of situations 
a continuum of policy activities (Lindblom 1959). Neither of these policy models provides an explanation of rational agency, which pragmatist philosophy does.

Policy processes never start anew in a vacuum, but occur in a socio-historical continuum. In pragmatist philosophy, a "practical starting point" for rational agency is the experience of an indeterminate situation within this continuum. Hildebrand (1999) makes a useful distinction between practical and theoretical starting points. The "raw experience" of an indeterminate situation is not neutral to past experiences, habitual transactions, or theoretical understanding; indeed it is partly constituted by these. A "practical starting point" means that a course of inquiry is motivated by the immediate imperatives and constraints of indeterminate situations, not by abstract, pre-existing theoretical positions. We start with experience and as it puts us on the spot, we choose different theoretical frameworks (including of previous policy experiences) as potential tools for creating meaning and orientation in problematic situations.

In policy-making, indeterminate situations can arise for a variety of institutional, political, moral, and intellectual reasons (Baumgartner and Jones 1991; Kingdon 1995). Potential policy problems may arise when: political ideologies change (e.g., China changing from a Marxist to a market economy); research and innovation reveal new possibilities (e.g., the development of alternative fuel technologies); new targets for policy processes are developed (e.g., the Millennium Development Goals); there is economic or social mobilization (e.g., the Orange Revolution in Ukraine); or there are special developments in policy networks (Huckfeldt et al. 2004; Sabatier 1988).

Not all indeterminate situations become, or should become, public policy problems. Dewey proposed that the boundaries of the public be "drawn on the basis of the extent and scope of the consequences of acts which are so important as to need control, whether by inhibition or by promotion"; with public officials and organizations coordinating this process (Dewey 1954/1927, p. 13). Here, public policy-making is initiated by the need to manage externalities and promote public goods, rather than by a priori social roles or contracts. The latter approach is propagated in early theories of liberalism and in later theories of social justice (Dewey 1939/1989a, 1954/1927). Sometimes, even though indeterminate situations have public policy implications they may be systematically kept off policy agendas. Classic policy case studies on "non decision-making" show, for example, how the topic of air pollution was kept off local policy agendas when companies that were major polluters were also major employers in these locations (Bachrach and Baratz 1962; Crenson 1971).

\section{The rhythm of situations as a template for the transactive rationality model}

The rhythm of situations provides a template for the transactive rationality model, as depicted in Fig. 3. This model takes both a descriptive and a normative stance.

The transactive rationality model provides an account of the typical elements in policymaking and the related challenges and dynamics. At the same time, the model incorporates Dewey's method of "inquiry" (described in a later section), as a rational way to organize policy processes toward the successful resolution of problematic situations. Each element of the model is discussed with reference to the pragmatist postulate to which it relates. The second pragmatist postulate relates to the formation of rational agency through communities of inquiry. 


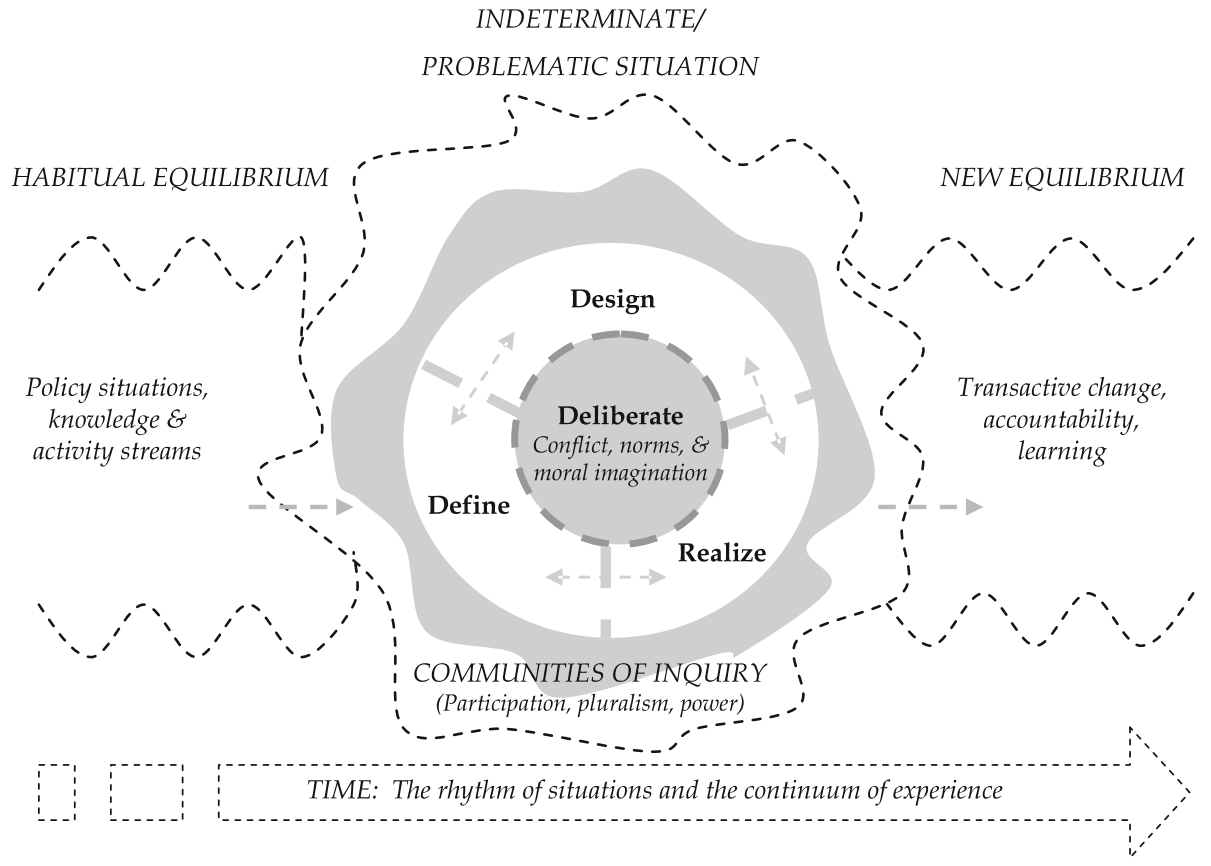

Fig. 3 The transactive rationality model

\section{Postulate II. Rationality is a product of inquiry in democratic communities}

Most theories of rationality wrongly assume that there is a pre-existing "agent," or an independent entity with predefined preferences and motivations for action (Joas 1996; Mousavi and Garrison 2003). From a pragmatist perspective neither an agent nor an agent's preferences are pre-determined. For Dewey the "actor" (i.e., the locus and author of agency) is a "confused and confusing word. ... 'Actor' should always be taken as postulationally transactional, and thus as a trans-actor" (Dewey 1925-1953/1999, p. LW 16.260). From this transactive view, Dewey (1954/1927) and Mead (1913/1982) explained that neither the individual nor society can be considered in isolation; individuals and societies are mutually constitutive through ongoing transactions in communities. Dewey held a position, aligned with Jefferson's, that the "community" was the foundation of democratic practice:

Unless local communal life can be restored, the public cannot adequately resolve its most urgent problem, to find and identify itself. (Dewey 1954/1927, p. 216)

Dewey recognized that communities are not built on physically contiguity alone, as they also have a functional basis. In fact, Dewey foresaw that "to a very considerable extent, groups having a functional basis will probably have to replace those based on physical contiguity" (Dewey 1939/1989a, p. 123). Dewey's theory of communities of inquiry was developed and tested in practice through his extensive collaboration with Jane Addams on a range of social policy projects, including on progressive education and on settlement projects at the Hull House (Shields 2003). 
In order to resolve indeterminate situations, agency develops through individuals and groups forming "communities of inquiry" (Dewey 1954/1927; Shields 2003). Policy scientists similarly describe networks, advocacy coalitions, and policy subsystems that form around policy issues (Heclo 1978; Sabatier 1988). These are groups that share "basic values, causal assumptions, and problem perceptions - and who show a non-trivial degree of coordinated activity over time" (Sabatier 1988). Sabatier (1988) describes how advocacy coalitions that form around policy issues such as air pollution control are constituted by public sector organizations, congressional committees, corporations, special interest groups, journalists, and research institutes for whom this issue is relevant.

In the transactive rationality model (Fig. 3), "communities of inquiry" form a dynamic boundary around an indeterminate situation and determine and demarcate a policy problem. This demarcation distinguishes activities relevant to defining and resolving the indeterminate situation, from the habitual transactions occurring externally (Dewey 1954/ 1927; Shields 2003). In the transactive rationality model, communities of inquiry have three key characteristics: participation; pluralism; and power.

In considering participation in policy-making, the ultimate goal is not to have everyone participating all the time, as this would be impracticable, inefficient, and ineffective (Benhabib 1986; Cooke and Kothari 2001; Habermas 1987; Shook 2004). Dewey strongly recommended that, in coordinating democratic inquiry, publics be identified on a functional basis determined by who, and what, is required to resolve problematic policy situation (Dewey 1954/1927; Shields 2003; Shook 2004). For those coordinating public policy processes, stakeholder analysis methods can help identify relevant actors, their interests, and positions to the policy issue being considered (Brugha and Varvasovsky 2000; Reich 1996). These considerations may change throughout the policy process, so the boundaries of the transactive rationality model are (and should be) flexible and permeable to ongoing changes in policy networks and problematic situation.

Pluralism is an important consideration in the constitution of communities of inquiry. Individuals define themselves, and the communities they form, differently with respect to different problematic situations. A scientist may be an expert on one topic and a lay person on another. Someone may be the beneficiary of one policy option and stand to lose with another option. Scholars recognize that paying attention to a diverse range of socio-cultural practices, perspectives, and choices is more useful from a political and legal perspective, than the focus on singular "identities," such as gender, race, or religious affiliation (Charlesworth and Chinkin 2000; Sen 2006). Dewey emphasized that pluralism is not only a reality, but also an intellectual resource on which societies should draw to resolve problematic situations (Dewey 1954/1927). Dewey proposed two criteria for assessing "social intelligence": (i) the level of pluralism in a society's intellectual resources and (ii) the extent to which these pluralistic resources are freely available for inquiry to resolve problematic situations (Dewey 1954/1927). In emphasizing the importance of pluralistic intellectual resources, Dewey cautioned against the search for panaceas, using the example of inquiry into health:

Health is a comprehensive, a "sweeping" ideal. However, progress toward it has been made in the degree in which recourse to panaceas has been abandoned and inquiry has been directed to determinate disturbances and means for dealing with them. (Dewey 1939/1989a, p. 129)

Dewey did not see why this type of inquiry into specific problems should not extend to socio-political and economic research, rather than the continual quests for political panaceas: capitalism, socialism, laissez faire individualism, and so on. 
Several theories of public deliberation focus on power as a primary force, whether positive or negative (Foucault 1984; Habermas 1987; Lukes 1974). Dewey observed that power is usually seen as a constructive force in oneself, but as a negative force in others (Dewey 1922/2002). He posited that developing reliable methods of public inquiry and deliberation could obviate the use of power as brute force. Similarly, based on his analyses of social policy-making internationally, Heclo (1974) points out the general, misplaced, tendency to overestimate the role of power, and underestimate the role of inquiry and deliberation.

In the transactive rationality model, power delimits participation and shapes all the decision activities, but carries no commitment to centralized or hierarchical forms of power. On the contrary, power as an element of the transactive model boundary is more a reminder that all the individuals and groups involved in the activities of "Define," "Design," "Realize," and "Deliberate," and in surrounding policy environments, can all potentially shape inquiry, and contribute to defining and resolving problematic policy situations. However, the challenges faced by public policy institutions to facilitate pluralistic participation, and to constructively channel power, cannot be underestimated. Related critiques are extensively documented in the literature, and research on improving methods of participation and deliberation is evolving (Benhabib 1986; Cooke and Kothari 2001; Habermas 1987; Huckfeldt et al. 2004; Isaacs 1999).

With communities of inquiry forming the basis of rational agency, the oft-cited chasm between scientific expertise and democratic participation is not unbridgeable. In fact, Dewey saw a clear connection between democracy and science. Ryan (1995) explains this link:

Dewey thought of democratic processes as a search procedure in which we look for policies, laws, and administrative techniques that will allow us to continue a common life in a way that all of us can find fruitful and fulfilling ... The nearest he got to a single account of democracy's virtues was that they were similar to those of science: It excluded the fewest alternatives, allowed all ideas a fair shot at being tried out, encouraged progress, and did not rely on authority. (Ryan 1995, pp. 313-314)

\section{Postulate III. Rationality integrates scientific, moral, and ecological reasoning}

Dewey's approach to democratic and scientific inquiry owes much to Charles Sanders Peirce's 3 "Doubt-Belief" scheme. Peirce (1831-1958) ${ }^{4}$ defined inquiry as a collective social enterprise that aims to settle "doubt." Contrary to the Cartesian model of inquiry, in classical pragmatism "doubt" is more than the theoretical possibility of calling a proposition into question or generating a hypothesis. "Doubt" is an existential state, a crisis of belief that challenges previously successful, or functional, knowledge and methods. Peirce's position was that doubt, just as belief, needs good reasons (Peirce 1931-1935). Joas (1993) explains the role of doubt in pragmatist inquiry:

Doubt becomes necessary only when well-established certainties no longer stand the test of reality or when subjects raise objections to the certainties of other subjects.

\footnotetext{
${ }^{3}$ Charles Sanders Peirce, William James, and John Dewey are considered the founding triumvirate of classical pragmatist philosophy. Jane Addams and George Herbert Mead, with whom Dewey worked closely, were also key to the development of classical pragmatism.

${ }^{4}$ Unless otherwise indicated, all references to Peirce refer to this collection of his study.
} 
The purpose of this doubt is to bring about new certainties through creative problem solving. (Joas 1993, p. 61)

Scientific inquiry takes place in a universe that is partly indeterminate, and abidingly suspended in the process of its own creation. Knowledge and laws are neither exact nor immutable; they are fallible and, at best, probabilistic. Human knowledge has moved beyond the thinking in the Middle Ages that the world is flat. ${ }^{5}$ Medical science now relies on anatomy and physiology rather than on the "humors" of medieval medicine (Foucault 1973/1963). There are also contemporary knowledge shifts, for example, when the harmful effects of currently approved medicines become evident in the longer-term, necessitating knowledge and policy change.

Putnam and Conant (1995, p. 152) highlights the unique contribution that pragmatist philosophy makes by integrating antiscepticism, wherein doubt requires as much justification as belief, and fallibilism, wherein there is no metaphysical guarantee that any belief is forever above revision. In the commitment to fallibilism as a source of scientific and political improvement, Dewey's pragmatist philosophy and Popper's philosophy of science $(1945,1959)$ are aligned. However, in contrast to Popper's piece-meal perspective on societal change, and to Lindblom's (1959) view of decentralized, incremental policy change, Dewey offers a vision of the public as a "great community" where people can envision and engage in large-scale social projects (Ryan 1995, pp. 100-101). Hickman explains: "Dewey argues instead for evolutionary continuities and for a commonality among human beings that is supported by those shared developments...that include communication and that provide the basis for objective tests of putative goods" (Hickman 2004, p. 497).

Dewey saw indeterminate policy situations arising as much from thinking about, and imagining future situations, as from more explicit, immediate changes in policy environments (Dewey 1929/1999, p. LW.4.182). For example, disruptions in policy equilibrium can occur from thinking about the implications of climate change for future generations, or about the challenges to pension and social security systems as a result of changing population demographics. The transactive rationality model embraces Dewey's method of inquiry and the "scientific attitude" (Dewey 1920/1999, p. 228; Shields 2003). A pragmatist policy-maker thus would not only seek to remedy symptoms of failure after they occur, but would also proactively and creatively think about solutions to avoid future impasses and to facilitate innovation, progress, and flourishing. Rather than settling for "muddling through," rummaging through "garbage cans" or being led by an "invisible hand," pragmatism proposes a more forward-looking approach of "socially intelligent inquiry." Dewey recommended that the scientific attitude be cultivated in societies, and even delighted in, to be open to the realities and possibilities of change (Dewey 1920/1999; Shields 2003).

The actions employed to resolve problematic situations result in learning, and thus shape self and society. Deliberation on societal choices and consequences is, hence, a fundamentally moral activity, and cannot be limited to a utilitarian or mathematical costbenefit analysis. As Dewey cautioned:

Deliberation is then not to be identified with calculation, or a quasi-mathematical reckoning of profit and loss. Such calculation assumes that the nature of the self does

\footnotetext{
5 Notwithstanding Thomas Friedman's 2005 book, The World is Flat, which proposes that globalization is a flattening factor.
} 
not enter into the question ... Every choice sustains a double relation to the self. It reveals the existing self and it forms the future self. (Dewey 1994, p. 141)

Traditionally in policy science, rationality models do not take morality into account. Political goals and public preferences are not evaluated as these are generally taken as fixed or given. As Herbert Simon averred:

Reason is wholly instrumental. It cannot tell us where to go; at best it can tell us how to get there. It is a gun for hire that can be employed in the service of any goals we have, good or bad. (Simon 1983, pp. 7-8)

Analyses of this "amoral" approach to rational decision-making in the Vietnam War, highlight the associated dangers, both moral and strategic (DeLeon and Longobardi 2002; Garrison 2000; Richardson 2002). The extensive technical calculations and mathematical modeling failed to take into account critical moral and cultural considerations. These, however, were among the main reasons for the worldwide protests and U.S. failures in this war (DeLeon 1988). Aligned with this critical thinking, in 2009, President Obama spoke out against torture as a means to ensure national security, as this contravened the core values and very identity of the nation established in the U.S. Constitution:

I know that we must never, ever, turn our back on its enduring principles for expedience sake. I make this claim not simply as a matter of idealism. We uphold our most cherished values not only because doing so is right, but because it strengthens our country and it keeps us safe. (White House Briefing 2009) ${ }^{6}$

Hence, how does pragmatist philosophy address morality with respect to rationality? There are strident criticisms of Dewey because he does not provide a substantive moral standard (Ryan 1995; Schilpp and Hahn 1939/1989). Dewey (1939/1989b), however, did not think that philosophers should set moral standards for the rest of society. Instead, he proposed that by improving methods of rational inquiry and deliberation, certain moral principles would emerge through societies' efforts to coordinate collective action, resolve problematic situations, and promote learning and flourishing. Thereafter, compelling reasons would be required to doubt these evolutionary moral precepts (as doubt, just as belief, requires warrant). This approach strengthens our moral principles against the onslaught of an all-encompassing skepticism, without falling prey to the trap of trying to settle moral questions once and for all (without the option of sensible review and application in specific cases and changing circumstances). As with scientific inquiry, in pragmatist philosophy, the balance between fallibilism and antiskepticism is the basis for moral inquiry and learning (Dewey and Tufts 1908/1999). The evolution of international human rights law illustrates this process.

Human rights were not explicitly referred to until the Scientific Enlightenment in the seventeenth century (Edmundson 2004). Dewey (1919/1999) noted this as a correspondence, or coincidence: "There has been, roughly speaking, a coincidence in the development of modern experimental science and of democracy." Monarchy and religious orthodoxy were rejected for every individual's dignity and access to knowledge. In the centuries after the Enlightenment and through the French Revolution, the American Declaration of Independence, World War II, and the Universal Declaration of Human Rights, human rights thinking evolved, entered the lingua franca of global politics, and became codified in international law (Edmundson 2004; Steiner and Alston 2000). Human

${ }^{6}$ White House Briefing, May 21, 2009 (http://www.whitehouse.gov/blog/Security-and-Values/). 
rights standards may make demands beyond what is immediately expedient. Nevertheless, these general principles provide an agreed-upon foundation for directing long-term social coordination and for developing shared practices that are valued by individuals and societies across the world. There are ongoing disagreements on the application of human right standards to specific problematic situations. From the pragmatist perspective, human right standards can, and should, be tested and evolve in this way.

In order to guide moral inquiry, Dewey put forward an Ethical Postulate that he hoped individuals and societies would test in different problematic situations.

The conduct required truly to express an agent is, at the same time, the conduct required to maintain the situation in which he is placed: while, conversely, the conduct that truly makes the situation is that which furthers the agent. ... The postulate is verified by being acted upon. The proof is experimental. (Dewey 1897/ 1999, p. 234)

Westbrook (1991) highlights a significant progression in Dewey's study in the evolution of this Ethical Postulate. An earlier version this postulate maintained was that we must not see individual good and social welfare as competing moral ends because personal benefit and the common good are complementary and essentially depend on one another. This later version extends this thinking to a more ecological focus on "situations" as a whole. Here Dewey maintains that not only are the individual and the social good mutually dependent, but also that human beings are part of interdependent systems, or situations, in nature. Thus, how natural resources are used, the extent to which this use is sustainable, and the interdependencies of ecologies and human experience, are key considerations in the pragmatist approach to rationality (Alexander 2002; Dorstewitz and Kuruvilla 2007).

\section{The logic of inquiry as the method for rational agency}

By Dewey's (1922/2002, p. 192) definition, agency requires "method" to be rational. In order to develop this method, Dewey analyzed different types of inquiry used in scientific experiment, common sense, mathematical logic, and even musical composition, to review: "specific sorts of inquiry and reach a generalized account of knowing through analyses of the features they present" (Dewey 1939/1989b, p. 557). Dewey defined inquiry as follows:

Inquiry is the controlled or directed transformation of an indeterminate situation into one that is so determinate in its constituent distinctions and relations as to convert the elements of the original situation into a unified whole. (Dewey 1938/1999, p. 117)

Five main elements constitute the logic of inquiry:

i. Indeterminate situations are experienced where harmonious, habitual, and functional interaction is interrupted or challenged, stimulating intentional action.

ii. Institution or intellectualization of a problem refers to the process of modifying an indeterminate situation into a "problematic" situation, where the issue is framed in a way that allows it to be addressed.

iii. The determination of problem-solutions gives new meaning to the expression that "a problem well-put is half-solved" (Dewey 1939/1989b). A problem is formulated with respect to possible solutions or hypotheses. The concepts of having a problem and finding a solution are interrelated and mutually constitutive. 
iv. Deliberation and judgment are not only analogous to the process of testing hypotheses, but also includes deliberation and judgment on intentions, potential consequences, norms, and moral orientation. Shared purposes can be developed through reflection or imagination of solutions and their consequences, leading to commitments on action to resolve problematic situations.

v. Restoration of harmonious experience occurs when inquiry manages to systematically harmonize conceptions with experience, resolve problematic experience, and regain equilibrium and functional coordination.

Pragmatist scholars caution against interpreting Dewey's logic of inquiry as a method of scientific experiment (Hickman 1995; Manicas 2002). The term "experimental" does not capture Dewey's integrated view of what is "experiential," i.e., the mutually formative transactions of agents and conditions in situations. Dewey was also explicit on the distinctions between the methods and objectives of pragmatism and empiricism:

Pragmatism is an extension of historical empiricism with this fundamental difference that it does not insist on antecedent phenomena, but on consequent phenomena, not upon precedents, but upon the possibilities of action-and this change in point of view is almost revolutionary in its consequences. An empiricism which is content with repeating facts already past has no place for possibility and for liberty. (Dewey 1925/1999, p. LW.2.13)

Based on Dewey's logic of inquiry, the internal structure of the transactive rationality model is constituted by four activities: Define, Design, Realize, and Deliberate. These activities could be read in a linear fashion, for example, following a sequence of Define $\rightarrow$ Design $\rightarrow$ Deliberate $\rightarrow$ Realize. The activities could also take place concurrently, separately, or iteratively, and they all influence each other. The fluid, permeable nature of the internal divisions of the transactive rationality model, and the ongoing interaction between the "decision cell" and the policy environment further inhibits a linear reading of the model. All activities are considered formative in policy-making. This model thus does not pivot around a central point at which strategic decisions are taken. The transactive rationality model eschews the linear instrumental separation between intellectual and practical phases (i.e., between planning and implementation). The idea behind a circular ordering of these activities is to acknowledge, and encourage, transactions in any direction and at any stage of the process. The distinctions made between the different decision activities are of a heuristic nature, as will be discussed in the following sections.

\section{Define}

Many traditional rationalistic policy models have problem identification stages where given problems, interests, and policy agendas are negotiated. In the pragmatist view, in response to an indeterminate situation, a situation is explored and problems defined (rather than identified). Once an indeterminate situation is defined as problematic situation that requires a public policy intervention (as discussed under the section on communities of inquiry), suggestions are developed for what Dewey calls "problem-solutions" (Dewey 1938/1999). Problems and solutions are not separate, distinct categories. A particular definition of a situation is concomitant with a particular solution. In the development of the Americans with Disabilities Act, analyses show the issue of access for disabled people to public spaces and buildings had at least two alternative policy frames or definitions: as a 
transport issue and as an anti-discrimination issue (Kingdon 1995; Richardson 2002). Each definition had very different policy implications and consequences, i.e., to provide special modes of transport, or to ensure the social integration of people with disabilities by modifying public spaces and transportation, which reflected the values of the civil rights movement at the time. Ultimately, it was a combination of the two approaches that resulted-a policy "end" that was not initially conceived.

The emphasis in the mode of define is on developing an understanding of indeterminate situations and exploring ways of resolving them. This is a mode where brainstorming, empirical and epidemiological analysis, concept development, narratives, and the arts all have application. Specific techniques, such as "problem-structuring methods," have been developed to systematically work through the process of defining problematic situations and possible solutions (Rosenhead and Mingers 2001).

\section{Design}

Influenced by the "problem-solutions" developed during the define phase, design is an activity where possible resolutions of indeterminate situations are explored and evaluated. Analyzing the available evidence, developing technical models and operational strategies, including allocation of resources and roles, assessing constraints and feasibility, and formulating related policy options are all part of the design phase.

Design is probably the most technical or "formal" phase in policy-making. Dewey's approach to socially intelligent inquiry recommends drawing on a range of pluralistic resources in society to resolve problematic situations and further recognizes that there are diverse dimensions and definitions possible in any situation. Dewey did see a specific, but not "privileged," role for scientific expertise in policymaking, that lay not in "framing and executing policies, but in discovering and making known the facts, upon which the former depend," as well as in carrying out specific technical functions as part of a larger community of inquiry working to resolve a problematic situation (Dewey 1954/1927). "Technical" here refers to the idea that experts and scientists have the skills to organize the facts to inform policy deliberations, not that experts should design and decide policy on their own. Part of the policy design process is facilitating public valuation of possible solutions. Public commentary on proposed policies is, for example, a required component of federal rule making in the U.S. and other countries. As illustrated in earlier cited examples of the Vietnam War protests (DeLeon 1988) and public commentary on FDA regulations (Roth et al. 2003), moral framing of policy issues can "trump" technical and economic frames.

The products of design activity often take the form of technical, legal or policy documents, for example technical specifications and guidelines, operational or strategic models and scenarios, budgets, bills, treaties, legal contracts, policy directives and guidelines, and public commentary (Buse et al. 2005; Lomas 1990). At this stage, agreed upon principles and plans of action are widely communicated to develop a shared vision of the proposed policy. Architects effectively communicate such overarching plans and visions, not by means of complicated formulae or technical details but with a "blue print" that clients can comment on, and based on which different groups can visualize their individual roles within the entire picture. ${ }^{7}$

7 c.f. R. L. Ackoff (2007) How to avoid the fatal F-Laws: Global Business, an interview with Peter Day. BBC World Service. 


\section{Deliberate: conflict, imagination, and norms}

In order to resolve indeterminate policy situations, individuals and groups may engage in a cooperative process of inquiry and deliberation, or engage in a more adversarial process. Several parliamentary systems are based on an adversarial system of political deliberation. Experts can, and do, interpret evidence differently and, indeed, use evidence to lobby for different policies and interests, or to support different positions, as in a court of law (Irwin 2001; Longino 2002; Salwen and Stacks 1996; Smith and Wynne 1989). However, lessons learned in the Greek polis and in contemporary studies on deliberation in policy networks, indicate that confrontation inhibits the development of new ideas, knowledge, and progress (Huckfeldt et al. 2004; Isaacs 1999). Dewey acknowledged the ubiquity of conflict in problematic situations and explained that deliberation was required to understand and resolve these conflicts:

Conflict is acute... Deliberation is not an attempt to do away with this opposition...

It is an attempt to uncover the conflict in its full scope and bearing. (Dewey 1922/

2002, p. 216)

Improved methods of negotiation, conflict resolution, and consensus development can facilitate non-confrontational deliberation and support collaborative action to resolve problematic policy situations (Drager et al. 2000; Hutchings et al. 2006; Isaacs 1999).

Dewey defines deliberation as "a dramatic rehearsal (in imagination) of various competing possible lines of action" (Dewey 1922/2002, p. 190). Dewey viewed both intelligence and imagination as the ability "to see the actual in the light of the possible" (Alexander 1993, p. 384). In science, imagination plays a role in discoveries and "breakthroughs." Through imagination artists explore and communicate "those potencies in things by which an experience-any experience-has significance and value" (Dewey 1934/1980, p. 192). In policy-making, imagination facilitates "safe" exploration and deliberation on alternative plans of action and their consequences and thus helps prevent premature commitment to any one option.

One method that supports the use of imagination and dramatic rehearsal in policymaking is scenario development. Scenario development is identified as "good practice" for developing forward-looking and innovative policies, and for anticipating and managing policy change (Cabinet Office 1999). Scenario development is used in a range of policy contexts: for example, in climate change deliberations (Nakicenovic et al. 2000) and in considering alternative scenarios for health care reform (Wanless 2002). In scenario development, a set of plausible "futures" is described using a matrix of alternative scenarios (Koehler and Harvey 2004). The implications of these scenarios, the indicators that one or the other scenario may be playing out, and contingency plans to meet related opportunities and risks are also considered.

In anticipating change, established norms are relatively stable guides across different situations. In policy-making, Sabatier discusses three overlapping levels of norms: (i) ideologies and deep core beliefs; (ii) basic political values or strategies; (iii) specific policy measures (Sabatier 1988). Though specific policy measures may be relatively open to negotiation and change, change becomes increasingly difficult when moving up this typology of norms. Changing core ideologies may be as complicated as effecting religious conversions.

Pragmatist philosophy portrays norms and ideals as useful points of orientation in the choppy sea of changing situations. However, unlike in other schools of philosophy, in pragmatism, norms and ideals should not be considered as ultimate standards or goals: 
True ideals are the working hypothesis of action; they are the best comprehension we can get of the value of our acts ... not that they set up remote goals. Ideals are like stars; we steer by them not towards them. (Dewey 1897/1999, p. EW.4.262)

The pragmatist paradox is the following: How can norms and ideals serve as reliable orientation points if they must be flexible enough to address the demands of changing situations? In pragmatist inquiry, norms are considered "intellectual instruments to be tested and confirmed — and altered—-through consequences effected by acting upon them" (Dewey 1929/1999, p. LW.4.221). Despite their relative stability as the products of an evolving social learning process, norms will always require interpretation and application in specific problematic situations (Alexander 1993; Dewey and Tufts 1908/1999). This concept is played out in legal systems where established laws have to be interpreted and applied. If existing laws do not clarify and resolve problematic situations, they can be revised, but only through a rigorous process of inquiry and deliberation.

\section{Realize}

Realize, as the term suggests, incorporates elements of "putting into practice," "evaluating," and "learning." This activity is in line with the pragmatist concept of change wherein any effected change in a situation is concomitant with changed experience in that situation (Dewey 1938/1999). This breaks down the linear sequence between (1) "implementing change"; (2) "learning from experience"; (3) "changing dispositions and actions." "Learning by doing" is an insufficient concept to sum up this interrelationship between experience, learning, and change. In the pragmatist model, realize extends to the overall process of restoring harmonious experience and equilibrium through changes in the overall situation comprising agents, environments, and transactions. The implication is that the implementation of any change amounts to a transformation of the way agents act. The process of "realizing" comprises what organizational change theorists Argyris and Schön's termed "double loop learning" (Argyris and Schön 1978). In this type of learning process, mutually influencing changes occur in actors' knowledge and values as well as in their organizational or policy environments.

Classic studies of policy implementation show that ongoing, discretionary decision making by bureaucrats and managers at "street-level" is inevitable, and even desirable, in the implementation and administration of policies and programs (Lipsky 1976; Pressman and Wildavsky 1984). As Garrison (2000, p. 473) comments:

Astute administrators see their ends clearly and revise them as necessary; only a fool would bypass a greater good merely to execute the original plan, although that is what linear, detached instrumentalism will often require the administrator to do.

However, discretionary decisions can render policies and programs unrecognizable from their planned formulation (Pressman and Wildavsky 1984). Further, these discretionary, implementation-related changes come about in an autocratic, undemocratic, or arbitrary manner (Richardson 2002). In order to improve the rationality of public policymaking, the process by which "ends" and "means" are revised should also be a scientific, democratic, and moral process. The permeable and variable boundaries of the transactive rationality model recognize that decision making is ongoing throughout the process of policy-making. 
Activities in the realize mode include the implementation of agreed upon policies, and developing or revising evaluation criteria and methods (an element that most models of rational deliberation see as part of earlier definition phases). Failure to realize hypothesized effects or to meet agreed upon benchmarks would require changes to be made to the original plans. These changes can be achieved through a coordinated process of policy inquiry involving deliberation and changes in define or design activities, or in the composition of communities of inquiry.

\section{Transactive change, accountability, and learning}

The fluid boundaries of the transactive model depicts that structural change in agents and environments occurs through ongoing transactions. Darwin's evolution of species is a good example with which to study change from a transactive perspective (Dewey 1910/1997; Hickman 2004). Yet, Dewey presents the transactive formation of agency and change as more than just a product of evolutionary chance. He distinguished between three categories of active and creative change that agents intentionally employ to resolve problematic experiences and to restore equilibrium (Dewey 1934; Joas 1996).

- Adaptation involves altering the external environment to match the agent's needs (e.g., preventing diseases by building sanitation and hygiene facilities).

- Accommodation, is internally oriented and involves an alteration within the agent. Agents rethink a situation and learn to maintain and develop functional transactions when conditions or circumstances cannot be changed (e.g., learning to live with a chronic disease or a seemingly intractable policy problem).

- Adjustment or transformative change refers to a more complex situational change where, through mutually referential transactions, both agents and environments change (e.g., the evolution of a species with changes in both the species and its environment, or changes in policy organizations and policy contexts that are mutually referential). This type of systemic change is aligned with theories of organizational change such as Argyris and Schön's concept of "double loop learning" (Argyris and Schön 1978) and with Vickers' concept of change in "appreciative systems" of policy-making (Vickers 1965).

The objectives of change, in the pragmatist view, are to regain functional coordination and equilibrium, and to promote learning and flourishing. Transactive change results in a new dynamic equilibrium and in new learning and transactions. These transactions become habitual, and are then challenged anew in the ongoing rhythm of situations.

One of the main challenges of a transactive, participatory model of policy-making is locating authority and accountability. Weiss analyzes the reasons why roles and responsibilities in public policy-making are difficult to pin down:

Three conditions that mainly account for the disavowals of decision-making authority [are]: (1) the dispersion of responsibility over many offices and the participation of many actors in decision-making, so that no one individual feels that he or she has a major say; (2) the division of authority among federal, state, and local levels in the federal system; and (3) the series of gradual and amorphous steps through which many decisions take shape. (Weiss 1980, p. 399)

Accountability is a focus of much policy and governance research and practice. In Norway, the ministry of health developed an accountability matrix approach to explicitly 
define accountability relationships in health systems management and to assess performance (WHO 2007). A better understanding of policy-making, and making explicit the actors, conditions, and criteria involved in rational decision-making, could help participants in policy processes better understand their respective roles, responsibilities, and related accountabilities.

This section concludes the development of the transactive rationality model and illustrates how a pragmatist reconstruction of rationality can be transposed to a theory of policy-making. Based on pragmatist philosophy, this model integrates the democratic, scientific, ecological, and moral dimensions of rational agency that can be used to resolve problematic situations, and support individual and societal flourishing.

\section{Postulate IV. Rationality is only successful if it serves as a guide towards satisfactory consequences in both theory and practice}

The pragmatist criteria for the success of rational policy-making are usefully considered in light of the differences between classical Deweyan pragmatism and Rortyian neo-pragmatism. ${ }^{8}$ Neo pragmatist philosopher Richard Rorty venerated Dewey, partly, because of their mutual rejection of reality as something externally fixed and given, with experience serving as a mere receptacle for nature's spectacle. In the same way as Dewey, Rorty (1980) explains that epistemic processes are active in creating both our beliefs and the objects of our belief.

Rorty parts company with Dewey when it comes to Dewey's definition of experience as a natural process that is "existential" or "real," and inquiry as an ongoing quest within the context of experience (cf. Hildebrand 2005). Rorty declared that all attempts to define "objective" criteria for the success of rationality or scientific common sense are made in vain. He advised the scientific community to abandon the pointless quest for truth and objectivity. Where empiricists saw experience to be an external and impartial judge of theory and inquiry (a position rejected by Dewey), Rorty saw references to experience as constructs developed through deliberations in specific conversations or contexts, which had established rules or standards.

Both Peirce and Dewey would have disavowed this reduction of inquiry and deliberation to a parlor game, in which participants play by rules and standards that have no justification other than the fact that these rules were agreed upon. Dewey criticized early modern empiricists for reducing experience to an impression from the outside, leaving the subject passive and receptive. In a similar vein, Dewey would have argued with Rorty, who reduced experience to an arbitrary form of linguistic practice. Hildebrand sees quite clearly that Dewey's conception of experience is richer than Rorty's because it can account for both the productive and the receptive aspects of experience (Hildebrand 2005). Hildebrand cites Dewey from Experience and Nature: "Only upon reflective analysis does [experience] break up into external conditions... and internal structures." Thus, experience, or the resolution of its problematic quality, is not an independent, predetermined criterion for successful inquiry.

Dewey precisely defines the indeterminate quality of changing situations as lacking clear criteria, such as defined problems, goals, or performance measures. Such criteria must

\footnotetext{
8 A series of debates in the journal Administration and Society addressed the differences between classical pragmatism and neo-pragmatism with reference to public administration and policy-making. See Shields (2003, 2005), Miller (2004), Hickman (2004), Hildebrand (2005), etc.
} 
be creatively constructed and defined through the process of rational inquiry and deliberation. Alternative definitions of problems and solutions will have alternative success criteria. In the earlier example of the alternative framing of the Americans with Disabilities Act as either a transportation issue or as a civil rights issue, each policy option would have had different success criteria e.g., related to efficiency of transportation or to the level of social integration.

Experience poses a real, existential constraint to sensible definitions of problems and effective solutions. The constraints and continuum of previous policy processes are an inherent and integral part of the pragmatist concept of the rhythm of situations and the continuum of experience. Further, although creating solidarity in the methods of inquiry and deliberation may be a central concern in scientific and policy communities, it cannot replace the quest for viable resolutions of problematic experience. A politically successful argument, or consensus, may not solve the problem it seeks to address. Edelman's (1977) book, "Words that succeed and policies that fail," suggests that this thinking is equivalent to the expression "the operation was successful, but the patient died." The ultimate test of pragmatist rationality is in practice. The final result of rational agency should be consummated in experience, and not just in reflection or imagination as Dewey emphasizes:

There are however vices of reflection as well as of impulse. We may not look far enough ahead because we are hurried into action by stress of impulse; but we may also become over interested in the delights of reflection; we become afraid of assuming the responsibilities of decisive choice and action. (Dewey 1922/2002, p. 198)

Dewey defined the successful outcome of rational inquiry as achieving a working harmony between diverse values, desires, and their anticipated consequences. The objective of inquiry is the directed transformation of a fragmented, indeterminate situation "into a unified whole" (Dewey 1938/1999, p. 117). Dewey thus imbues the success of rational inquiry with an aesthetic akin to the transcendental composite of ens, bonum, verum, pulchritudum, unum; or of experience, ethics, science, and art that compose a unity. Pragmatism does not consider this aesthetic unification as a deterministic or a natural end, but as a possibility or potential that can be achieved through rational agency. People are attuned to thinking about successful policy-making in this way when they comment on "elegant" policy solutions, or about how all the right pieces came together in policy deliberations. As Dewey concluded: "Order, rhythm, and balance, simply means that energies significant for experience are acting at their best" (Dewey 1934/1980, p. 192)."

\section{Conclusion}

The title of this article claimed: "there is no 'point' in decision-making." In contrast to the linear rational model (Fig. 1), the transactive rationality model (Fig. 3) shows that decision-making is not a fixed central point that separates pre-defined ends and inquiry phases from subsequent implementation and evaluation phases. Definitions and decisions are formed, and informed, throughout the policy process. Transactive rationality, like incrementalism, recognizes that policy inquiry and deliberation occur within a continuum of experience. Contrary to incrementalism, by integrating scientific and democratic inquiry with moral imagination, transactive rationality supports integrative, visionary, and forward-looking public policy and democratic projects. By addressing the scientific, democratic, moral, and ecological dimensions of rational agency, transactive rationality provides 
a more holistic, explanatory, and normative "fourth approach" to policy-making-beyond "linear" and "bounded" rationality, "incrementalism," and "mixed scanning," the transactive rationality model, to meet the pragmatist standard of success, needs to be tested and developed in both theory and practice.

This article contributes to a growing body of study that applies classical pragmatist philosophy to the political and policy sciences and public administration. As Seigfried observes, pragmatism's greatest strengths are now being rediscovered:

These include early and persistent criticisms of positivist interpretations of scientific methodology; disclosure of the value dimension of factual claims; reclaiming aesthetics as informing everyday experience; linking of dominant discourses with domination; subordinating logical analysis to social, cultural, and political issues; realigning theory with praxis. (Seigfried 1996, p. 21)

Contemporary studies indicate that pragmatist philosophy can better explain political and economic behavior, rather than other related theories (Mousavi and Garrison 2003; Shook 2003). Pragmatist philosophy also offers an ecological perspective on policy-making that emphasizes the interdependence of actors and environments (Alexander 2002; McDonald 2004). This is an important policy perspective given growing concerns for ecological sustainability and security. With its emphasis on holism and equilibrium, and on learning and progress, pragmatist philosophy is attuned with both Eastern and Western systems of thought, a key policy consideration in this globalizing world (Grange and Ames 2004; Westbrook 1991). Evans argues that: "it would be not only possible, but also prudent, for the field of public management to reclaim the philosophy of John Dewey as a guiding ethos for its practice".

One fundamental concern about pragmatist philosophy is whether it is overly optimistic about individuals' and societies' capacities for rational deliberation (Bernstein 1998; Ryan 1995). Bernstein notes that such optimism indeed could be viewed as a fault, but emphasizes that Dewey's was a qualified optimism:

I do think that at times Dewey is excessively optimistic about the real social and political possibilities of resolving serious social conflicts by open communication. Although this is a weakness in Dewey's thinking, we can read him in a different way. For we can interpret Dewey as telling us that it is precisely because conflicts between different groups run so deep, that it becomes all the more urgent to develop those habits and virtues by which we can intelligently seek to negotiate and reconcile differences. (Bernstein 1998, p. 149)

"The problem of the public," as Dewey himself admitted, is the essential need for "improvement of the methods and conditions of debate, discussion and persuasion" (Dewey 1954/1927, p. 208). The strong confluence of pragmatist philosophy and policy science continues to channel inquiry into improving the methods of rational deliberation in public policy and democratic practice.

Open Access This article is distributed under the terms of the Creative Commons Attribution Noncommercial License which permits any noncommercial use, distribution, and reproduction in any medium, provided the original author(s) and source are credited.

\footnotetext{
${ }^{9}$ Dewey was influenced by his international work, and his philosophy is internationally recognized. He worked not only in the U.S. and Europe, but also in Japan, Turkey, Mexico, South Africa, and Russia (Schilpp and Hahn 1939/1989; Westbrook 1991; Ryan 1995). In China, he was even considered a "second Confucius" (Grange and Ames 2004; Westbrook 1991).
} 


\section{References}

Ackoff, R. L., \& Emory, F. E. (2005). On purposeful systems: An interdisciplinary analysis of individual and social behavior as a system of purposeful events. New Brunswick: Aldine Transaction.

Alexander, T. (1993). John Dewey and the moral imagination: Beyond Putnam and Rorty toward a postmodern ethics. Transactions of the Charles S. Peirce Society, 19(3), 369-400.

Alexander, T. (2002). The aesthetics of reality: Dewey's ecological theory of experience. In T. F. Burke, D. M. Hester, \& R. B. Talisse (Eds.), Dewey's logical theory. Nashville: Vanderbilt University Press.

Argyris, C., \& Schön, D. A. (1978). Organizational learning: A theory of action perspective. Reading: Addison Wesley.

Bachrach, P., \& Baratz, M. S. (1962). Decisions and nondecisions: An analytical framework. American Political Science Review, 56(2), 632-642.

Baumgartner, F. R., \& Jones, B. D. (1991). Agenda dynamics and policy subsystems. Journal of Politics, 53(4), 1044-1074.

Benhabib, S. (1986). Critique, norm and utopia. A study of the foundations of critical theory. New York: Columbia University Press.

Bernstein, R. J. (1998). Community in the pragmatist tradition. In M. Dickstein (Ed.), The revival of pragmatism: New essays on social thought, law and culture (pp. 141-156). Durham, NC: Duke University.

Brugha, R., \& Varvasovsky, Z. (2000). Stakeholder analysis: A review. Health Policy and Planning, 15(3), 239-246.

Buse, K., Mays, N., \& Walt, G. (2005). Making health policy. Maidenhead: Open University Press.

Cabinet Office. (1999). Professional policy making for the twenty first century. London: Strategic Policy Making Team, Cabinet Office.

Caspary, W. R. (2000). Dewey on democracy. Ithaca: Cornell University Press.

Charlesworth, H., \& Chinkin, C. (2000). The boundaries of international law: A feminist analysis. Manchester: Manchester University Press.

Checkland, P. (1999). Systems thinking, systems practice: Includes a 30-year retrospective. Chichester: Wiley.

Cohen, M. D., March, J. G., \& Olsen, J. P. (1972). A garbage can model of organizational choice. Administrative Science Quarterly, 17, 1-25.

Cooke, B., \& Kothari, U. (Eds.). (2001). Participation: The new tyranny?. London: Zed Books.

Crenson, M. A. (1971). The unpolitics of air pollution: A study of non-decision making in the cities. Baltimore: Johns Hopkins University Press.

deHaven-Smith, L. (1988). Philosophical critiques of policy analysis: Lindblom, Habermas and the Great Society. Gainesville: University of Florida Press.

DeLeon, P. (1988). Advice and consent: The development of the policy sciences. New York: Russell Sage Foundation.

DeLeon, P., \& Longobardi, R. C. (2002). Policy analysis in the Good Society. The Good Society, 11(1), 37-41.

Dewey, J. (1897/1999). The study of ethics. In J. A. Boydston \& L. A. Hickman (Eds.), The collected works of John Dewey, 1882-1953. The electronic edition. Carbondale: Southern Illinois University Press/ Charlottesville: InteLex 'Past Masters' series.

Dewey, J. (1910/1997). The influence of Darwin on philosophy and other essays. London: Prometheus Books.

Dewey, J. (1919/1999). Philosophy and democracy. In J. A. Boydston \& L. A. Hickman (Eds.), The collected works of John Dewey, 1882-1953. The electronic edition. Carbondale: Southern Illinois University Press/Charlottesville: InteLex 'Past Masters' series.

Dewey, J. (1920/1999). Reconstruction in philosophy. In J. A. Boydston \& L. A. Hickman (Eds.), The collected works of John Dewey, 1882-1953. The electronic edition. Carbondale: Southern Illinois University Press/Charlottesville: InteLex 'Past Masters' series.

Dewey, J. (1922/2002). Human nature and conduct: An introduction to social psychology. New York: Henry Holt/Mineola: Dover.

Dewey, J. (1925-1953/1999). The later works of John Dewey, 1925-1953. In J. A. Boydston \& L. A. Hickman (Eds.), The collected works of John Dewey, 1882-1953. The electronic edition. Carbondale: Southern Illinois University Press/Charlottesville: InteLex 'Past Masters' series.

Dewey, J. (1925/1999). The development of American pragmatism. In J. A. Boydston \& L. A. Hickman (Eds.), The collected works of John Dewey, 1882-1953. The electronic edition. Carbondale: Southern Illinois University Press/Charlottesville: InteLex 'Past Masters' series.

Dewey, J. (1929/1999). The quest for certainty. In J. A. Boydston \& L. A. Hickman (Eds.), The collected works of John Dewey, 1882-1953. The electronic edition. Carbondale: Southern Illinois University Press/Charlottesville: InteLex 'Past Masters' series. 
Dewey, J. (1934a). A common faith. New Haven: Yale University Press.

Dewey, J. (1934/1980). Art as experience. New York: Perigee Books.

Dewey, J. (1938/1999). Logic: The theory of inquiry. In J. A. Boydston \& L. A. Hickman (Eds.), The collected works of John Dewey, 1882-1953. The electronic edition. Carbondale: Southern Illinois University Press/Charlottesville: InteLex 'Past Masters' series.

Dewey, J. (1939/1989a). Freedom and culture. Amherst: Prometheus Books.

Dewey, J. (1939/1989b). The philosopher replies. Experience, knowledge and value: A rejoinder. In P. A. Schilpp \& L. E. Hahn (Eds.), The philosophy of John Dewey (3rd ed., pp. 515-608). La Salle: Open Court.

Dewey, J. (1954/1927). The public and its problems. Athens: Swallow Press/Ohio University Press.

Dewey, J. (1994). In J. Gouinlock (Ed.), The moral writings of John Dewey. Great books in philosophy. New York: Prometheus Books.

Dewey, J., \& Bentley, A. F. (1946). Interaction and transaction. The Journal of Philosophy, 43(19), 505-517.

Dewey, J., \& Tufts, J. H. (1908/1999). Ethics. In J. A. Boydston (Ed.), The collected works of John Dewey, 1882-1953. The electronic edition. Carbondale: Southern Illinois University Press/Charlottesville: InteLex 'Past Masters' series.

Dorstewitz, P., \& Kuruvilla, S. (2007). Rationality as situated inquiry: A pragmatist perspective on policy and planning. Philosophy of Management, 6(1), 91-118.

Drager, N., McClintock, E., \& Moffitt, M. (2000). Negotiating health development: A guide for practitioners. Cambridge: Conflict Management Group and World Health Organization.

Durie, M. (2004). Understanding health and illness: Research at the interface between science and indigenous knowledge. International Journal of Epidemiology, 33(5), 1138-1143.

Edelman, M. (1977). Political language: Words that succeed and policies that fail. New York: Institute for the Study of Poverty.

Edmundson, W. A. (2004). An introduction to rights. Cambridge: Cambridge University Press.

Elster, J. (1991). The cement of society: A study of social order. Cambridge: Cambridge University Press.

Etzioni, A. (1967). Mixed scanning: A 'third approach' to decision-making. Public Administration Review, 27(5), 385-392.

Evans, K. G. (2000). Reclaiming John Dewey: Democracy, inquiry, pragmatism, and public management. Administration \& Society, 32(3), 308-328.

Foucault, M. (1973/1963). The birth of the clinic. London: Tavistock.

Foucault, M. (1984). In P. Rabinow (Ed.), The Foucault reader. London: Penguin Books.

Garrison, J. (2000). Pragmatism and public administration. Administration \& Society, 32(4), 458-477.

Grange, J., \& Ames, R. T. (2004). John Dewey, Confucius, and global philosophy. New York: SUNY Press. Habermas, J. (1987). The theory of communicative action (2nd ed.). Cambridge: Polity Press.

Hall, R. H. (1977). Organizations, structure, and process. Englewood Cliffs: Prentice Hall.

Heclo, H. (1974). Modern social policies in Britain and Sweden: From relief to income maintenance. New Haven: Yale University Press.

Heclo, H. (1978). Issue networks and the executive establishment. In A. King (Ed.), The new American political system. Washington DC: American Institute for Public Policy Research.

Hickman, L. A. (1995). Pragmatism, technology, and scientism: Are the methods of the scientific-technical disciplines relevant to social problems? In R. Hollinger \& D. Depew (Eds.), Pragmatism-from progressivism to postmodernism (pp. 72-88). Westpoint, CT: Praeger.

Hickman, L. A. (2004). On Hugh T. Miller on "why old pragmatism needs an upgrade". Administration \& Society, 36(4), 496-499.

Hildebrand, D. L. (1999). Pragmatism and literary criticism: The practical starting point. REAL: Yearbook of Research in English and American Literature, 15, 303-322.

Hildebrand, D. L. (2005). Pragmatism, neopragmatism, and public administration. Administration \& Society, 37, 345-359.

Huckfeldt, R., Johnson, P. E., \& Sprague, J. (Eds.). (2004). The survival of diverse opinions within communication networks. Cambridge: Cambridge University Press.

Hutchings, A., Raine, R., Sanderson, C., \& Black, N. (2006). A comparison of formal consensus methods used for developing clinical guidelines. Journal of Health Services Research \& Policy, 11(4), 218-224.

Irwin, A. (2001). Constructing the scientific citizen: Science and democracy in the biosciences. Public Understanding of Science, 10, 1-18.

Isaacs, W. (1999). Dialogue and the art of thinking together. New York: Currency Doubleday.

Joas, H. (1993). Pragmatism and social theory. Chicago: University of Chicago Press.

Joas, H. (1996). The creativity of action. Chicago: The University of Chicago Press. (Originally published by Suhrkamp Verlag, 1992)

John, P. (1998). Analysing public policy. London: Pinter. 
Kingdon, J. W. (1995). Agendas, alternatives, and public policies (2nd ed.). New York: Harper Collins College Publishers.

Koehler, D. J., \& Harvey, N. (Eds.). (2004). Blackwell handbook of judgment and decision making. Oxford: Blackwell.

Lasswell, H. D. (1971). A pre-view of policy sciences. New York: Elsevier.

Lindblom, C. E. (1959). The science of “muddling through". Public Administration Review, 19, 79-88.

Lipsky, M. (1976). Towards a theory of street-level bureaucracy. In W. Hawley \& M. Lipsky (Eds.), Theoretical perspectives on urban policy. Englewood Cliffs: Prentice Hall.

Lomas, J. (1990). Finding audiences, changing beliefs: The structure of research use in Canadian health policy. Journal of Health Politics, Policy and Law, 15, 525-542.

Longino, H. E. (2002). The fate of knowledge. Princeton: Princeton University Press.

Lukes, S. (1974). Power: A radical view. London: Macmillan.

Manicas, P. T. (2002). John Dewey and American psychology. Journal for the Theory of Social Behaviour, 32(3), 268-294.

McDonald, H. P. (2004). John Dewey and environmental philosophy. Albany: State University of New York Press.

Mead, G. H. (1913/1982). The social self. In H. S. Thayer (Ed.), Pragmatism: The classic writings. Indiana: Hackett.

Meyerson, M., \& Banfield, E. C. (1955). Politics, planning, and the public interest: The case of public housing in Chicago. London: The Free Press of Glencoe.

Miller, H. T. (2004). Why old pragmatism needs an upgrade. Administration \& Society, 36(2), 243-294.

Mousavi, S., \& Garrison, J. (2003). Toward a transactional theory of decision making: Creative rationality as functional coordination in context. Journal of Economic Methodology, 10(2), 131-156.

Nakicenovic, N., Alcamo, J., Davis, G., de Vries, B., Fenhann, J., Gaffin, S., et al. (2000). Special report on emissions scenarios (SRES). Working Group III of the Intergovernmental Panel on Climate Change (IPCC). Retrieved April, 2007, from http://www.grida.no/climate/ipcc/emission/index.htm

Nelkin, D. (1975). The political impact of technical expertise. Social Studies of Science, 5, $37-54$.

Parsons, W. (1995). Public policy: An introduction to the theory and practice of policy analysis. Cheltenham: Edward Elgar.

Peirce, C. S. (1831-1958). Collected articles of Charles Sanders Peirce. Cambridge, MA: Harvard University Press.

Peirce, C. S. (1931-1935). In C. Hartshorne \& P. Weiss (Eds.), Collected articles (Vol. I-VI). Cambridge: Harvard University Press.

Popper, K. R. (1945). The open society and its enemies. London: Routledge.

Popper, K. R. (1959). The logic of scientific discovery. London: Hutchinson.

Pressman, J. L., \& Wildavsky, A. (1984). Implementation: How great expectations in Washington are dashed in Oakland; or why it's amazing that federal programs work at all, this being a saga of the economic development administration as told to two sympathetic observers who seek to build morals on a foundation of ruined hopes (3rd, expanded ed.). Berkley: University of California Press.

Putnam, H., \& Conant, J. (1995). Words and life. Cambridge: Harvard University Press.

Reich, M. R. (1996). Applied political analysis for health policy reform. Current Issues in Public Health, 2, 186-191.

Richardson, H. S. (2002). Democratic autonomy: Public reasoning about the ends of policy. New York: Oxford University Press.

Rorty, R. (1980). Philosophy and the mirror of nature. Oxford: Backwell.

Rosenhead, J., \& Mingers, J. (Eds.). (2001). Rational analysis for a problematic world revisited: Problem structuring methods for complexity, uncertainty, and conflict (2nd ed.). Chichester: Wiley.

Roth, A. L., Dunsby, J., \& Bero, L. A. (2003). Framing processes in public commentary on US federal tobacco control regulation. Social Studies of Science, 33(1), 7-44.

Ryan, A. (1995). John Dewey and the high tide of American liberalism. New York: W.W. Norton \& Company.

Ryan, A. (2000). What did John Dewey want? In J. Haldane (Ed.), Philosophy and public affairs. Cambridge: Cambridge University Press.

Sabatier, P. A. (1988). An advocacy coalition framework of policy change and the role of policy-oriented learning therein. Policy Sciences, 21(2-3), 129-168.

Sabatier, P. A. (Ed.). (1999). Theories of the policy process. Boulder: Westview Press.

Salwen, M. B., \& Stacks, D. W. (Eds.). (1996). An integrated approach to communication theory and research. Mahwah: Lawrence Erlbaum Associates.

Schilpp, P. A., \& Hahn, L. E. (Eds.). (1939/1989). The philosophy of John Dewey (3rd ed.). La Salle: Open Court. 
Schoenwandt, W. (2008). Planning in crisis? Theoretical orientations for architecture and planning. Surrey: Ashgate.

Seigfried, C. H. (1996). Pragmatism and feminism: Reweaving the social fabric. Chicago: Chicago University Press.

Sen, A. (2006). Identity and violence: The illusion of destiny. New York: W.W. Norton \& Company.

Shields, P. M. (1996). Pragmatism: Exploring administration's policy imprint. Administration \& Society, 28(3), 390-411.

Shields, P. M. (2003). The community of inquiry: Classical pragmatism and public administration. Administration \& Society, 35(5), 510-538.

Shields, P. M. (2005). Classical pragmatism does not need an upgrade: Lessons for public administration. Administration \& Society, 37(4), 504-518.

Shook, J. R. (2003). Entrepreneurship and values in a democratic and pragmatic economics: Commentary on 'a transactional view of entrepreneurship'. Journal of Economic Methodology, 10(2), 181-190.

Shook, J. R. (2004). Deliberative democracy and moral pluralism: Dewey vs. Rawls and Habermas. In J. Ryder \& K. Wilkoszweska (Eds.), Deconstruction and reconstruction. The Central European pragmatist forum (Vol. 2). Amsterdam: Rodopi.

Simon, H. A. (1957). Administrative behavior (2nd ed.). New York: Free Press.

Simon, H. A. (1983). Reason in human affairs. Stanford: Stanford University Press.

Smith, R., \& Wynne, B. (Eds.). (1989). Expert evidence: Interpreting science in the law. London: Routledge.

Snider, K. F. (2000). Response to Stever and Garrison. Administration \& Society, 32, 487-489.

Steiner, H. J., \& Alston, P. (2000). International human rights in context: Law, politics and morals (2nd ed.). Oxford: Oxford University Press.

Vickers, G. (1965). The art of judgment: A study of policy-making. London: Chapman \& Hall.

Vickers, G. (1978). Systems practice: Managing complexity. Open University interview with Sir Geoffrey Vickers. Retrieved from http://www.open2.net/systems/practice/sir.html

Wanless, D. (2002). Securing our future: Taking a long-term view. London: HM Treasury.

Weiss, C. (1980). Knowledge creep and decision accretion. Knowledge: Creation, Diffusion, Utilization, $1,381-404$.

Westbrook, R. B. (1991). John Dewey and American democracy. Ithaca: Cornell University Press.

WHO. (2007). EUR/08/5085699. Assessing health systems performance: First preparatory meeting for the WHO European ministerial conference on health systems: "Health systems, health and wealth". Brussels: World Health Organization Europe. 